\title{
Leaf extract of Osbeckia octandra induces apoptosis in oral squamous cell carcinoma cells
}

\author{
Jue Young Kim¹,2, Jin Kim', B. M. Ratnayake Bandara ${ }^{3}$, Wanninayake M. Tilakaratne ${ }^{4,5}$ and Dokyeong Kim ${ }^{1,6^{*}}$
}

\begin{abstract}
Background: Osbeckia octandra is a plant endemic to Sri Lanka and is used in ethnomedicine for treating various diseases. However, the anti-cancer properties of O. octandra are yet to be fully investigated. In the present study, we evaluated the anti-cancer effects of $O$. octandra on oral cancer cells.

Methods: Human oral cancer cell lines (HSC2, YD10B, YD38, YD9, and YD32) were used in this study. BrdU incorporation, cell cycle and annexin-V/PI staining were all evaluated using flow cytometry to determine the extent to which $O$. octandra leaf extract inhibits cell proliferation and induces apoptosis. Cell viability and reactive oxygen species (ROS) were also measured in order to investigate the anti-cancer effects of $O$. octandra extracts. Western blotting was performed to detect cell cycle related protein such as cyclin $\mathrm{d} 1$ and $\mathrm{cdk} 4$, and to detect apoptosis-related proteins such as BCl-2, BCl-X L, Bax, Caspase-9, Cleaved caspase-3, Fas, Caspase-8, and Bid.

Results: Leaf extract of $O$. octandra reduced oral squamous cell carcinoma (OSCC) cell viability in a dose-dependent manner. Leaf extract of $\mathrm{O}$. octandra has non-toxic in normal keratinocytes. Also, O. octandra extract interrupted the DNA replication via G1 phase arrests, and this effect was independent of ROS generation. In the apoptosis-related experiments, the population of annexin $V$-positive cells increased upon treatment with $O$. octandra extract. Furthermore, the expression of anti-apoptotic protein ( $\mathrm{BCl}-2$ and $\mathrm{BCl}-\mathrm{xL}$ ) was decreased, whereas the expression of cleaved caspase-3 protein was increased in O. octandra-treated OSCC cells.
\end{abstract}

Conclusions: The results suggest that a leaf extract of $O$. octandra inhibited the proliferation of OSCC cells through $G_{1}$ phase arrest and interrupting DNA replication. The leaf extract of $O$. octandra could trigger the apoptotic response via caspase 3 activation in OSCC cells. These results suggest that $O$. octandra has the potential to be developed as an alternative medicine for treating OSCC.

Keywords: Osbeckia octandra, Cell cycle arrest, Apoptosis, Oral squamous cell carcinoma

\section{Background}

Herbal extracts have long been used as a resource for developing therapeutics $[1,2]$ because of their long history of use and their typically low toxicity. In recent years, as people worldwide have been searching for more natural alternatives to treat diseases, herbal extracts have

\footnotetext{
*Correspondence: dkkim2908@gmail.com

${ }^{6}$ Precision Medicine Research Center, Department of Biomedicine \& Health Sciences, College of Medicine, The Catholic University of Korea, Seoul 06591, Republic of Korea

Full list of author information is available at the end of the article
}

gained wide popularity as complementary and alternative medicines, especially in Asian countries [1, 3, 4].

The plant Osbeckia octandra (family Melastomataceae) is endemic to Sri Lanka, and is known as Heen Bovitiya locally [5]. The leaves and young stems are both edible, and the leaves, roots and bark are used in traditional medicines for treating diabetes mellitus, hepatitis, jaundice, hyperlipidemia, hemorrhoids and ascites. Additionally, the juice extracted from $O$. octandra leaves has protective effects against the liver damage induced by paracetamol poisoning [6], galactosamine and tert-butyl hydroperoxide [7]. The extracts of O. octandra have 
recently been shown to have anti-cancer effects on oral squamous cell carcinoma (OSCC), demonstrating that $O$. octandra can diminish OSCC cell migration and increase DNA fragmentation [8]. However, further studies are warranted to explore the effect of O. octandra on cancer cell proliferation and apoptosis. In this study, we found that the leaf extract of O. octandra hindered DNA replication via $G_{1}$ phage arrest and caused apoptosis in OSCC cells.

\section{Methods \\ Cell cultures}

HSC2 OSCC cells were purchased from the Japanese Collection of Research Bioresources Cell Bank (Shinjuku, Japan), and the cells were maintained in $\mathrm{F}$ medium composed of Dulbecco's modified Eagles medium (\#12800017, Gibco BRL, NY, USA) and F-12 Ham (\#21700-075, Gibco BRL, NY, USA) mixed in a 3:1 ratio and supplemented with $10 \%$ fetal bovine serum and $1 \%$ penicillin/ streptomycin. YD OSCC cell lines (YD9, YD32, YD38 and $\mathrm{YD} 10 \mathrm{~B})$ were grown in $\mathrm{F}$ medium, supplemented with $1 \times 10^{-10} \mathrm{M}$ cholera toxin (\#C8052), $0.4 \mathrm{mg} / \mathrm{ml}$ hydrocortisone (\#H4001), $5 \mu \mathrm{g} / \mathrm{ml}$ insulin (\#I9278), $5 \mu \mathrm{g} /$ $\mathrm{ml}$ transferrin (\#T1147) and $2 \times 10^{-11} \mathrm{M}$ triiodothyronine (T3, \#T2877) [9]. The supplements to culture YD OSCC cell lines were purchased from Sigma Aldrich, Merck KGaA, Darmstadt, Germany. Human normal epidermal keratinocytes (HEK) were obtained from primary culture and used below the 9th passage. Ethically, the use of HEK cells was approved by the Institutional Review Board (IRB) of the Yonsei Dental Hospital, Yonsei University Health System, Seoul, Republic of Korea (IRB-22009-0002) as in our previous study [10]. HEK cells were grown in KGM medium (\#CC-3107, Lonza, Basel, Switzerland). All the cells were kept in an incubator containing $5 \% \mathrm{CO}_{2}$ at $37^{\circ} \mathrm{C}$; the culture medium was changed every 3 days.

\section{Preparation of $O$. octandra leaf extract}

The leaves of $O$. octandra were collected using the correct collection permits by the curator of private garden in Kegalle, Sabaragamuwa Province, Sri Lanka. The botanical identity of the plant was confirmed by a field botanist (Mr. R. M. A. P. M. Rajatewa, Environmental Consultant, Educational and Rehabilitation Organisation, Gampaha, Sri Lanka) and authenticated at the Royal Botanical Gardens at Peradeniya, Sri Lanka; a voucher specimen (FAHS/OO/2013/01) of the plant has been deposited at the herbarium of the Department of Pharmacy, University of Peradeniya, Sri Lanka and is available for scientific studies upon request. The use of plant parts in the present study complies with international/national and institutional guidelines. The leaves were shade-dried for
6 weeks and ground to obtain a coarse powder using a mechanical grinder. The plant powder $(50 \mathrm{~g})$ was then shaken with dichloromethane and methanol (1:1, 1.5l) on a bottle shaker at room temperature for $24 \mathrm{~h}$. After decanting the solvent extract, the plant residue was extracted again with a fresh volume of solvent following the same procedure. The extracts were filtered using a Buchner funnel, filtrates combined, and the solvent evaporated to dryness in order to obtain the solvent-free dried extract. For in vitro experiments, the dried extract was dissolved in DMSO (\#D1370, Duchefa Biochemie, RV Haarlem, Netherlands) and the supernatant was used in the assays described below.

\section{Cell viability and cytotoxicity assay}

Cells were seeded into 96-well culture plates $\left(2 \times 10^{3} /\right.$ well) and treated with the indicated concentrations (50 to $300 \mu \mathrm{g} / \mathrm{ml}$ ) of $O$. octandra leaf extract for $72 \mathrm{~h}$ before MTT (\#M1415, Duchefa Biochemie, RV Haarlem, Netherlands) assays were performed to measure cell viability.

\section{BrdU incorporation}

After treatment with the O. octandra extract, a BrdU incorporation assay was performed to determine the frequency at which cells were synthesizing DNA. BD Pharmingen ${ }^{\mathrm{TM}}$ BrdU flow kits (\#559619, BD Biosciences, San Jose, CA, USA) were used following the manufacturer's instructions. In brief, cells were plated at $1 \times 10^{6}$ cells $/ 100 \mathrm{~mm}$ culture dish. Each plate was then maintained in the presence or absence of O. octandra leaf extract $(100 \mu \mathrm{g} / \mathrm{ml})$ for $24 \mathrm{~h}$ before the BrdU solution was carefully added directly to each culture medium. After incubation, BrdU stained cells were measured by flow cytometry (Becton Dickinson, Beckman Coulter) as per manufacturer's instruction. The DNA synthetic activity of cells was determined by analyzing the correlated expression of total DNA (7-AAD staining) and incorporated BrdU levels.

\section{Cell cycle analysis using flow cytometry}

Cell cycle analysis was carried out using propidium iodide (PI) staining. The cells were plated to $1 \times 10^{6}$ cells/100-mm culture dish and stabilized overnight. The next day, the cells were treated with $O$. octandra extract $(100 \mu \mathrm{g} / \mathrm{ml})$ for $12 \mathrm{~h}$ or $72 \mathrm{~h}$ before being harvested and fixed with ethanol in PBS. After centrifuging the cells, the cell pellets were incubated with an RNase A (\#10109169001, Roche, Basel, Switzerland) solution at $37^{\circ} \mathrm{C}$ for $30 \mathrm{~min}$ to which PI staining solution $(50 \mu \mathrm{g} / \mathrm{ml})$ was added. The cell cycle distribution was then analyzed by flow cytometry (BD FACSCanto II flow cytometer, BD Biosciences, Franklin Lakes, NJ, USA). 


\section{Reactive oxygen species (ROS) generation}

The generation of ROS was measured using flow cytometry [10]. Briefly, cells $\left(4 \times 10^{5}\right.$ cells/6-well plate) were grown with or without $O$. octandra extract $(100 \mu \mathrm{g} / \mathrm{ml})$ for $24 \mathrm{~h}$ and then $10 \mu \mathrm{M} \mathrm{2} 2^{\prime}, 7^{\prime}$-dichlorofluorescin diacetate $\left(\mathrm{H}_{2} \mathrm{DCFDA}\right.$ ) (\#D399, Molecular Probes Inc., Eugene, OR, USA) dissolved in DMSO was applied. After incubating at $37^{\circ} \mathrm{C}$ for $20 \mathrm{~min}$, the cells were detached and analyzed by flow cytometry (Beckman Coulter, Fullerton, CA, USA).

\section{Protein extraction and western blotting}

Cells $\left(1 \times 10^{6}\right.$ cells/100-mm culture dish $)$ were seeded and allowed to stabilize overnight. Cells were then lysed by using cell lysis buffer (\#9803, Cell Signaling Technology, Danvers, MA, USA) containing phenylmethanesulfonyl fluoride (PMSF, \#78830, Sigma Aldrich, Merck KGaA, Darmstadt, Germany) and the lysates were put on ice for $30 \mathrm{~min}$. After vortex mixing, the cell lysates were swirled every $5 \mathrm{~min}$. Lastly, the lysates were centrifuged, and the supernatant was stored at $-20^{\circ} \mathrm{C}$ until use. To perform the western blot, the obtained supernatants were mixed with $5 \mathrm{X}$ sodium dodecyl sulfate (SDS) sample buffer and loaded onto an SDS-PAGE gel. After running the gel, the protein bands were transferred to a PVDF membrane and blocked with 5\% skim milk in PBS with Tween 20 added. After blocking, the membranes were incubated with indicated primary antibodies at the appropriate diluted ratio given below.

The antibodies against Cyclin D1 (\#2978s, 1:1000, Cell Signaling Technology, Danvers, MA, USA), CDK4 (\#ab108357, 1:1000, Abcam, Cambridge, UK), Bcl-2 (\#sc-7382, 1:500, Santa Cruz Biotechnology, Dallas, TX, USA), Bcl-xL (\#sc-8392, 1:500, Santa Cruz Biotechnology, Dallas, TX, USA), Bax (\#ab32503, 1:1000, Abcam, Cambridge, UK), Caspase-9 (\#9502 s, 1:1000, Cell Signaling Technology, Danvers, MA, USA), and Cleaved Caspase-3 (Asp175, 1:1000, Cell Signaling Technology, Danvers, MA, USA), Fas (\#8023s, 1:1000, Cell Signaling Technology, Danvers, MA, USA), Caspase-8 (\#9746s, 1:1000, Cell Signaling Technology, Danvers, MA, USA), and Bid (\#2002p, 1:1000, Cell Signaling Technology, Danvers, MA, USA) were used. The secondary antibodies (anti-rabbit- (\#7074S) and anti-mouse-IgG, HRP-linked (\#7076S)) were purchased from Cell Signaling Technology (Danvers, MA, USA). $\beta$-Actin (\#BS6007M, 1:5000) that was purchased from Bioworld Technology, Inc. (St. Louis, MN, USA) was used as a housekeeping control.

\section{Annexin V and PI staining using flow cytometry}

YD10B and HSC2 cells $\left(5 \times 10^{5}\right)$ were grown in 100 $\mathrm{mm}$ dishes incubated at $37^{\circ} \mathrm{C}$ overnight. The cells were then treated with the $O$. octandra extract for the indicated period. Afterwards, the cells were stained using an annexin V-fluorescein isothiocyanate (FITC) kit (\#556547, BD Biosciences, San Jose, CA, USA) according to the manufacturer's protocol. Briefly, both types of cells were washed by cold PBS and then the cells were incubated with FITC annexin V and/or PI in 1X Binding Buffer for at room temperature $15 \mathrm{~min}$. The stained cells were then analysed by flow cytometry. For bar graphs, the fraction of early apoptotic cells was measured by detecting cells stained only with annexin V. A FC500 series CXP cytometer and CXP analysis (Beckman Coulter, USA) were used for measurement and data analysis, respectively.

\section{Statistical analysis}

All statistical analyses were performed using SPSS version 20 (SPSS Inc., Chicago, IL, USA). Differences between groups were analyzed using Mann-Whitney U tests. Each experiment was performed at least in triplicate. The results are reported as the mean \pm standard deviation (SD). A value of $P$-value $<0.05$ was considered statistically significant.

\section{Results}

Leaf extract of $O$. octandra reduced the viability in OSCC cells

To investigate the cytotoxicity of O. octandra extract to OSCC cells, we measured cell viability after treatment with $50-300 \mu \mathrm{g} / \mathrm{ml} \mathrm{O}$. octandra extract for $72 \mathrm{~h}$, using MTT assay. Compared with the control (DMSO), the treatment of $O$. octandra extract significantly reduced the viability of various OSCC cell lines $(* P<0.05)$ (Fig. 1a and Additional file 1: Fig. S1). Among them, the viabilities of YD10B and HSC2 cells were markedly reduced by the $O$. octandra extract in a dose-dependent manner (Fig. 1a). A concentration of $100 \mu \mathrm{g} / \mathrm{ml} \mathrm{O.} \mathrm{octandra}$ extract, which induced about $50 \%$ cell death in both types of OSCC cells, was selected for subsequent assays. There was no noticeable difference in cell viability between untreated- and extract-treated human-normal keratinocytes (HEK) cells (Fig. 1b). Taken together, O. octandra extract displayed cytotoxicity only to OSCC cells and was not toxic to normal keratinocytes.

\section{Leaf extract of $O$. octandra inhibited the proliferation of OSCC cells via cell cycle arrest in the G1 phase}

To investigate whether $O$. octandra extract would interrupt the DNA replication of OSCC cells, BrdU staining was performed. Our results clearly show that $O$. octandra extract interrupted the DNA replication of OSCC cells (Fig. 2a and b), decreased the DNA replication of YD10B cells from $15.53 \pm 3.50 \%$ (DMSO) to 


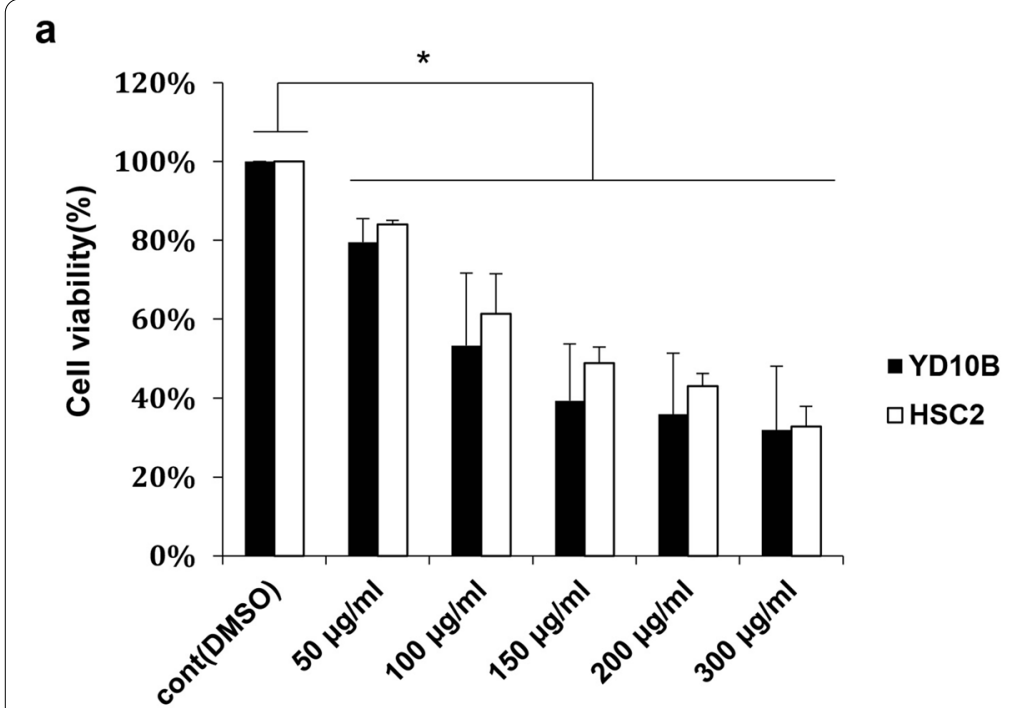

b

Fig. 1 Cell viability with O. octandra treatment in OSCC cells and HEK cells. a OSCC cells were seeded in 96-well culture plates $\left(2 \times 10^{3} /\right.$ well) and were treated with the indicated concentrations $(50$ to $300 \mu \mathrm{g} / \mathrm{ml}$ ) of 0 . octandra extract for $72 \mathrm{~h}$ before MTT assay was performed. The extract reduced the cell viability of HSC2 and YD10B cells in a dose-dependent manner. $\mathbf{b}$ HEK cells were seeded into 96-well culture plates ( $2 \times 10^{3} /$ well) and treated with $100 \mathrm{\mu g} / \mathrm{ml}$ of $O . o c t a n d r a ~ e x t r a c t$ for $72 \mathrm{~h}$ before MTT assay was performed ( ${ }^{*} P<0.05$, Mann whitney $\mathrm{U}$ test)

a

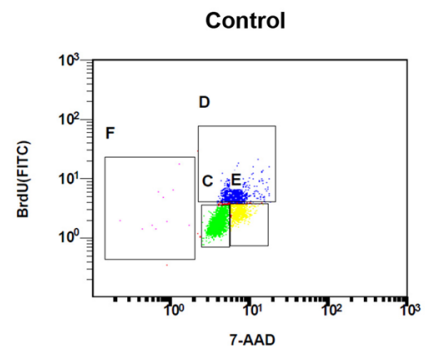

O.octandra

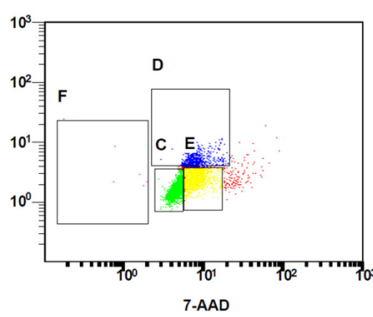

$*$

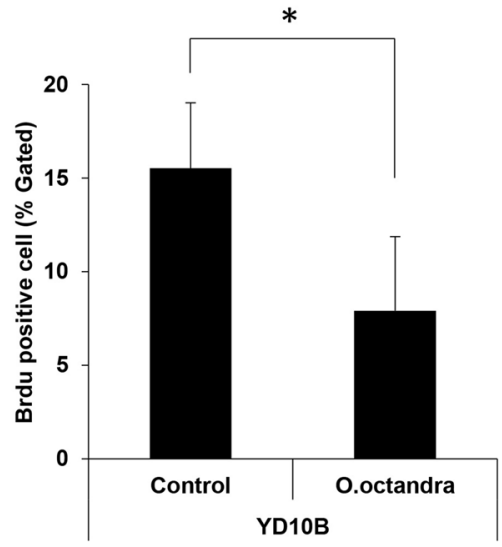

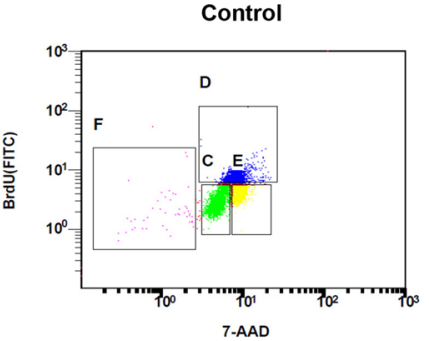
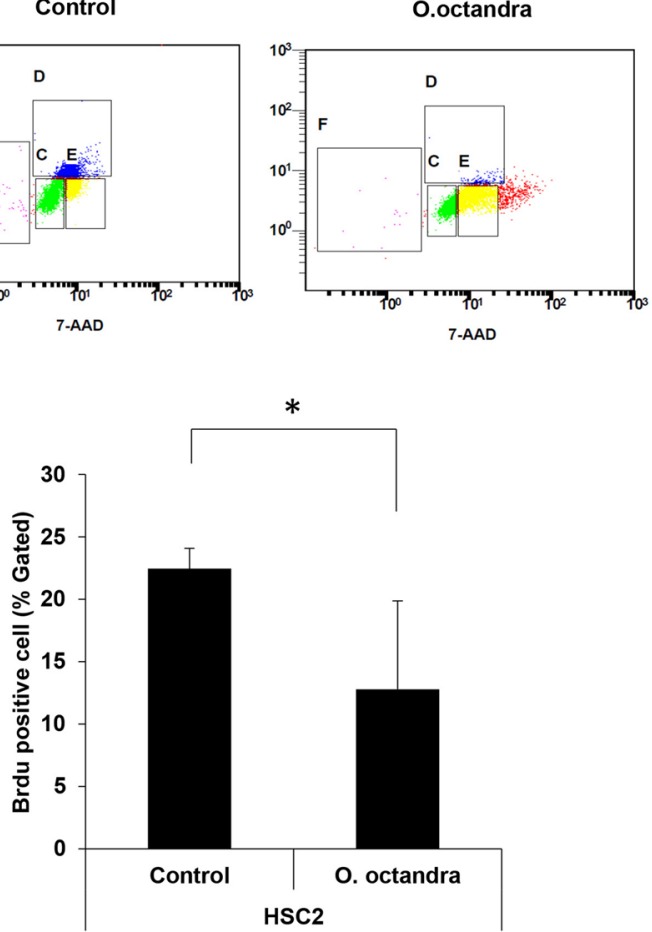

Fig. 2 The leaf extract of O. octandra interrupts DNA replication in OSCC cell. $\mathbf{a}$ and $\mathbf{b}$ YD1OB (a) and HSC2 (b) cells were plated at $1 \times 10^{6}$ cells $/ 100-\mathrm{mm}$ culture dish. Each well was maintained in the presence or absence of 0 . octandra $(100 \mu \mathrm{g} / \mathrm{ml})$ for $24 \mathrm{~h}$ before carefully adding the BrdU solution directly into the cultured medium. After incubation, BrdU staining was performed. The DNA synthetic activities of cells can be determined by analyzing the correlated expression of total DNA (7-AAD staining) and incorporated BrdU levels. The BrdU-positive cells in S-phase are represented by blue spots (upper panels) and their quantity is indicated by bar graphs (lower panels) $\left(^{*} P<0.05\right.$, Mann whitney $\mathrm{U}$ test) 
$7.91 \pm 3.96 \%$ (extract) (*P<0.05), and decreased the replication of HSC2 cells from $22.45 \pm 1.63 \%$ (DMSO) to $12.79 \pm 7.07 \%$ (extract) ( $P<0.05)$. We further verified the growth inhibitory activity of $O$. octandra extract on OSCC cells via cell cycle analysis. After treatment with $O$. octandra extract for $24 \mathrm{~h}$, our results show that extract-stimulated YD10B cells increased the proportion of cells in the G1 phase to $66.17 \pm 2.37 \%$ (**\% $P<0.001$ ) (Fig. 3a and Table 1). Similarly, extract-stimulated HSC2 cells increased the proportion of cells in the $G_{1}$ phase to $57.63 \pm 0.40 \%$ (Fig. $3 \mathrm{~b}$ and Table 1), compared with control cells (**** $P<0.001$ ). Furthermore, both cell types showed an increase in sub $G_{0} / G_{1}$ phase cells and a decrease in $S$ phase cells. The tendency is consistent with an increase in $G_{1}$ phase cells and a decrease in $S$ phase cells at $6 \mathrm{~h}$ after treatment with $O$. octandra extract (Table 1). It is indicating that $O$. octandra leaf extract increased the population of apoptotic cells. Additionally, we investigated the effect of O. octandra extract on the expression of cell cycle regulatory genes, which play a central role in the cell cycle progression and induced $\mathrm{G}_{1}$ phase arrest. $O$. octandra extract resulted in a clear a
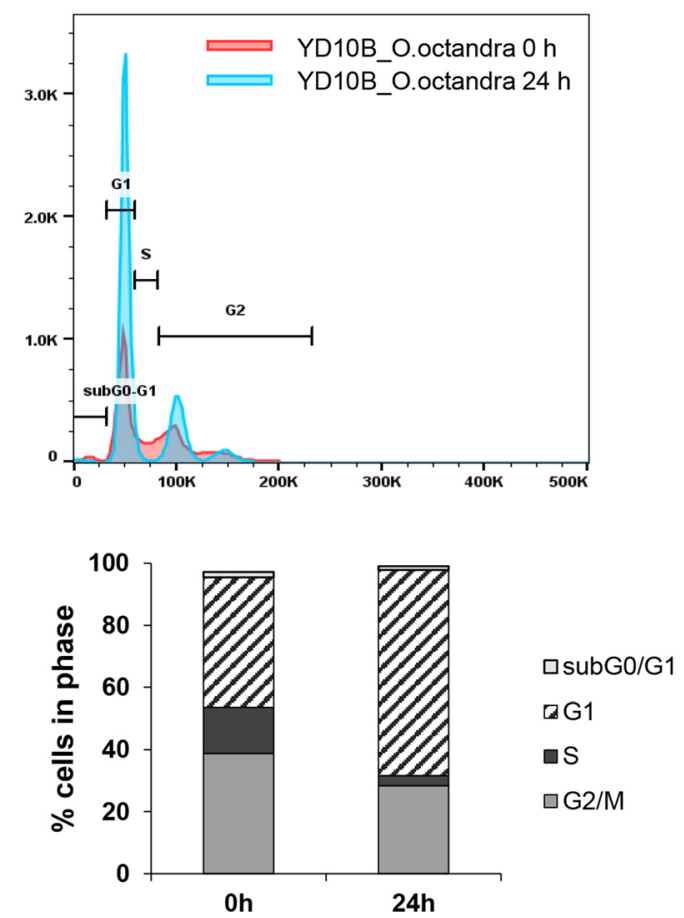

C

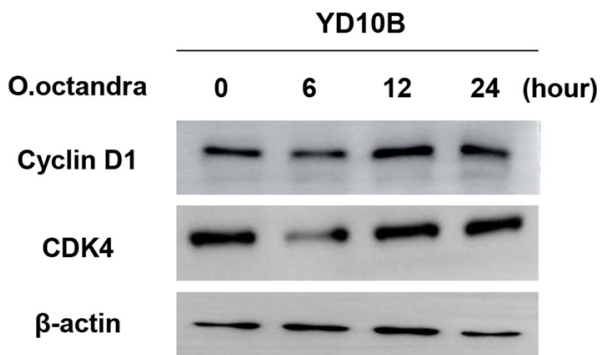

b
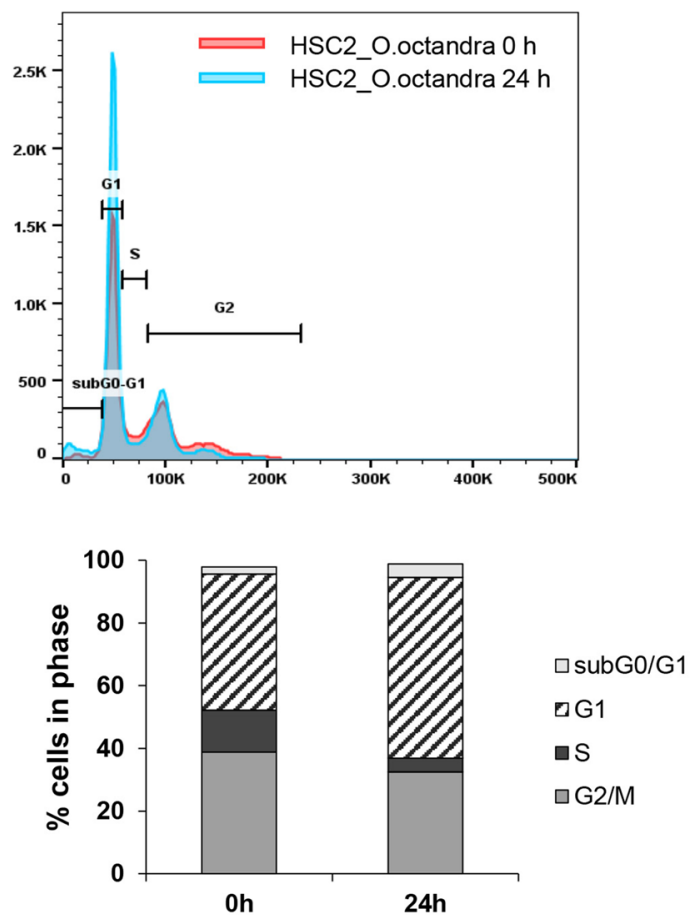

d

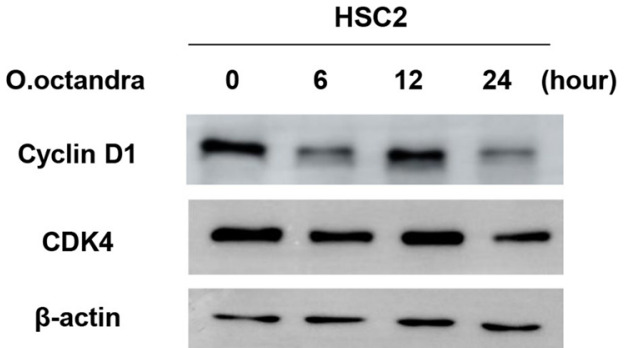

Fig. 3 The leaf extract of O. octandra induces cell cycle arrest in OSCC cell. $\mathbf{a}$ and $\mathbf{b}$ YD1OB (a) and HSC2 (b) cells were plated at $1 \times 10^{6}$ cells/100-mm culture dish, and then treated with $100 \mu \mathrm{g} / \mathrm{ml} 0$. octandra extract for the indicated time. Propidium iodide staining was performed, and the stained cells were analysed by flow cytometry to evaluate the cell cycle. The histograms for cell cycle analysis are represented at $24 \mathrm{~h}$ after treatment with 0 . octandra extract (upper panels; red line: $0 \mathrm{~h}$ skyblue line: $24 \mathrm{~h}$ ) and their quantity is indicated by bar graphs within cell cycle phase (lower panels) (*** $P<0.001$, Mann whitney $U$ test). The details were shown in Table 1. c and d YD10B (c) and HSC2 (d) cells were seeded at $1 \times 10^{6}$ cells $/ 100-\mathrm{mm}$ culture dish. After stabilizing for $24 \mathrm{~h}$, the cells were treated with $100 \mu \mathrm{g} / \mathrm{ml} 0$. octandra extract for the indicated time and harvested. Proteins were then extracted from the harvested cell lysates $(* P<0.05)$. Protein bands were separated on the same gel and were cropped. Full length of immunoblots was shown in Additional file 5: Fig. S5 
Table 1 Cell cycle profiles of OSCC cells treated with O. octandra extracts

\begin{tabular}{|c|c|c|c|}
\hline \multicolumn{4}{|c|}{ Cell cycle profiles of YD10B cells treated with 0. octandra } \\
\hline & \multicolumn{3}{|c|}{ Time } \\
\hline & TOh & T6h & $24 \mathrm{~h}$ \\
\hline Sub G0/G1 & $1.77 \pm 0.25$ & $3.63 \pm 4.55$ & $1.21 \pm 0.20$ \\
\hline G1 & $41.83 \pm 4.58$ & $52.03 \pm 13.55$ & $66.17 \pm 2.37$ \\
\hline S & $14.87 \pm 2.23$ & $15.77 \pm 2.40$ & $3.25 \pm 1.95$ \\
\hline $\mathrm{G} 2 / \mathrm{M}$ & $38.77 \pm 0.76$ & $27.83 \pm 15.93$ & $28.40 \pm 4.44$ \\
\hline \multicolumn{4}{|c|}{ Cell cycle profiles of HSC2 cells treated with 0 . octandra } \\
\hline & \multicolumn{3}{|c|}{ Time } \\
\hline & $\mathrm{Oh}$ & $6 \mathrm{~h}$ & $24 \mathrm{~h}$ \\
\hline Sub G0/G1 & $2.30 \pm 0.17$ & $6.41 \pm 1.83$ & $4.26 \pm 2.76$ \\
\hline G1 & $43.37 \pm 1.44$ & $47.90 \pm 5.74$ & $57.63 \pm 0.40$ \\
\hline S & $13.40 \pm 0.60$ & $9.86 \pm 0.09$ & $4.40 \pm 0.47$ \\
\hline G2/M & $38.87 \pm 1.23$ & $34.63 \pm 7.70$ & $32.53 \pm 2.75$ \\
\hline
\end{tabular}

Each value represents mean \pm SD of each performed in triplicated. SD Standard deviation

down-regulation in the protein expression levels of cyclin $\mathrm{D} 1$ at $6 \mathrm{~h}$ after treatment with $O$. octandra in both types of OSCC cells (Fig. 3c and Additional file 5: Fig. S5). Similarly, a marked decreased in the expression of CDK4 was detected at $6 \mathrm{~h}$ in both types of OSCC cells. These results showed that $O$. octandra extract decreased the protein expression of cyclin D1-CDK4 complex, confirming that $O$. octandra extract induces cellular apoptosis via cell cycle arrest in the G1 phase.

To understand how $O$. octandra leaf extract could trigger $G_{1}$ phase arrest and lead to apoptosis, we examined ROS generation; the latter could cause DNA damage and cell cycle arrest in a variety of conditions. Unexpectedly, the treatment with O. octandra extract decreased ROS generation in YD10B cells (4.63-fold decrease) and HSC2 cells (1.79-fold decrease), respectively (" $P<0.05$ ) (Additional file 2 : Fig. S2), suggesting that the extract of $O$. octandra functions as an antioxidant and does not cause ROS-induced DNA damage.

In summary, these results suggest that $O$. octandra extract mediates $G_{1}$ phase arrest, thereby retarding cell proliferation and subsequently promoting cellular apoptosis. These processes were not caused by $O$. octandrastimulated ROS generation; on the contrary, the leaf extracts of $O$. octandra extract are known to have antioxidant properties in vitro [11].

\section{Leaf extract of $O$. octandra caused apoptosis via caspase-3 cascade in OSCC cells}

To determine if O. octandra extract could induce apoptosis, we first performed annexin V and PI staining and the stained cells were analysed by flow cytometry. The proportion of annexin V-positive YD10B cells increased to
$41.67 \pm 16.21 \%$ (extract-treated) compared with control (DMSO-treated) cells $(13.17 \pm 3.57 \%)(* P<0.05)$ (Fig. 4a). Additionally, the proportion of annexin V-positive HSC2 cells increased to $41.45 \pm 14.74 \%$ compared with control (DMSO-treated) cells $(24.53 \pm 12.63 \%)(* P<0.05)$ (Fig. 4b). These results suggest that $O$. octandra-induced cell death is caused by apoptosis in OSCC cells.

Further, we investigated the effect of the leaf extract on the apoptosis-regulating protein, including $\mathrm{Bcl}-2$, Bcl$\mathrm{X}_{\mathrm{L}}$, Bax, Caspase-9, and Cleaved caspase-3. The expression of anti-apoptotic Bcl-2 and $\mathrm{Bcl}-\mathrm{X}_{\mathrm{L}}$ was decreased $6 \mathrm{~h}$ after treatment with $O$. octandra extract in both types of OSCC cells, whereas O. octandra extract treatment was clearly increased the expression of pro-apoptotic Bax after treatment with them in HSC2 cells. Lastly, $O$. octandra extract increased cleaved caspase- 3 in both types of OSCC cells (YD10B and HSC2), compared with control cells (Fig. 4c, d and Additional file 6: Fig. S6). Additionally, we investigated whether O. octandra extract can be initiated through activation of the extrinsic pathway (Additional file 3: Fig. S3 and Additional file 4: Fig. S4). As results, the protein levels of Fas were weakly increased at $24 \mathrm{~h}$ after treatment with $O$. octandra extract in only HSC2 OSCC cells, not in YD10B cells. Moreover, there is no tendency in protein expression of caspase- 8 and bid, which are the downstream of extrinsic pathway mediated by the death receptor. Taken together, these results suggest that cell death induced by $O$. octandra leaf extract is caused by intrinsic apoptotic pathway through caspase- 3 activation and the $\mathrm{Bax} / \mathrm{Bcl}-\mathrm{X}_{\mathrm{L}}$ and $\mathrm{Bcl}-2$ ratio in OSCC cells.

\section{Discussion}

OSCC is the most common malignant tumor among head and neck cancers and has a high rate of morbidity and mortality. For treatment in patient with OSCC, several therapies are used, which include conventional therapies such as surgery, chemotherapy, radiotherapy, or a combination of these depending on the tumor type. Unfortunately, these therapies come with abundant complications and only a moderate success rate [12]. For instance, chemotherapeutic drugs can exacerbate the hematologic toxicities like anemia, leukopenia and thrombocytopenia [13]. Additionally, the combinations of chemotherapy, radiotherapy and surgery could produce adverse effects on orofacial regions, such as hyposalivation, fibrosis of the temporomandibular joint (TMJ), chemotoxicity in the jaw, and fungal and/or bacterial infections of the mucosa [14]. Thus, alternative medicines with low toxicity would bring in numerous benefits in cancer therapy.

The plant $O$. octandra is used in traditional herbal medicine for treating jaundice and other liver diseases 


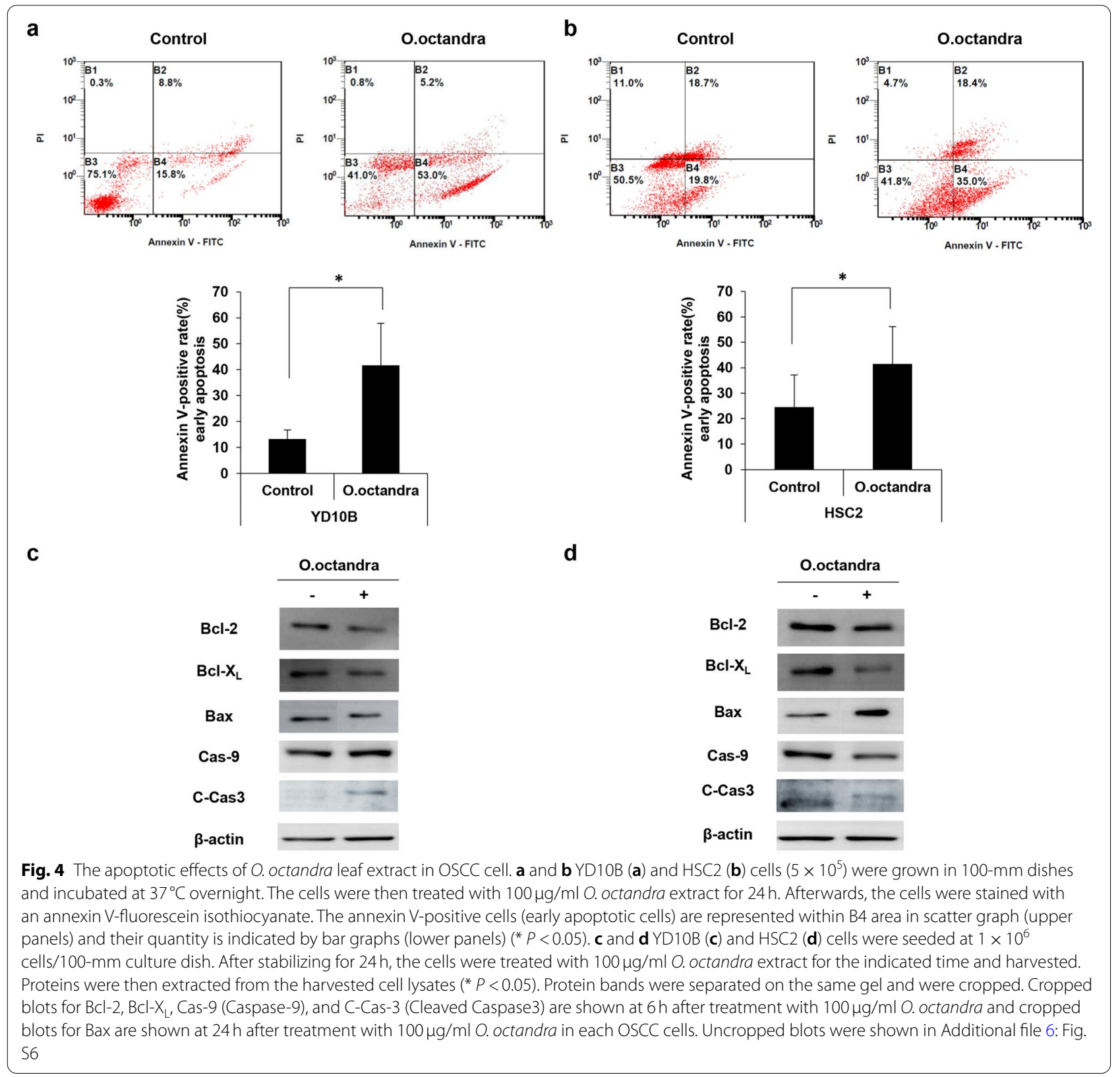

[5-7]. Recently, a leaf extract of O. octandra has shown in vitro anti-cancer effects on OSCC cells by reduction of cell migration and induction of DNA damage [8]. Whether O. octandra can induce apoptosis in OSCC cells remains to be explored. To this end, we performed various in vitro experiments to demonstrate the apoptotic effects of O. octandra leaf extract on OSCC cells. Our data reveal that O. octandra decreased OSCC cell viability and DNA replication while no significant damage was observed in HEK cells. Moreover, the treatment with $O$. octandra extract increased $\mathrm{G}_{1}$ cell populations. Thus, the cell death was most likely caused by $G_{1}$ arrest in both types of OSCC cells. Interestingly, $\mathrm{G}_{1}$ checkpoint arrest might also result in dissipating an exogenous cellular stress signal [15]. In addition to the $G_{1}$ checkpoint arrest, the $O$. octandra extract also increased the sub $\mathrm{G}_{0} /$ $\mathrm{G}_{1}$ cell population transiently, suggesting that the extract induced cellular apoptosis. Consistent with these observations, $G_{1}$ checkpoint signaling could result in the activation of pathways such as the p53 pathway, also leading to programmed cell death [15]. Similarly, our finding shows that $S$ checkpoint was upregulated in concomitant with $G_{1}$ checkpoint arrest. Cyclin D1, with its partner $C D K 4 / 6$, plays a dominant role in regulating $G_{1} / S$ 
cell cycle progression of various cancer cells $[16,17]$. Consistent with cell cycle profiles, we demonstrated that downregulation of cyclin D1 and CDK4 at an earlier (6h) treatment time point after treatment with $O$. octandra extracts, meaning that $O$. octandra extracts is sufficient to induce $G_{1}$ cell cycle arrest in OSCC cells.

$\mathrm{G}_{1}$ arrest is involved in the apoptotic pathways [18]. Conversely, we have previously reported that DNA damage is induced by ROS generation in OSCC carcinogenesis [10]. Based on the previous contention, we investigated whether O. octandra-induced DNA damage [8] is dependent with ROS. Contrary to expectations, $O$. octandra extracts suppressed the generation of $\mathrm{ROS}$, indicating that $O$. octandra functions as an antioxidant [11]. Taken together, these data suggest that the O. octandra-mediated DNA damage and $\mathrm{G}_{1}$ checkpoint arrest were independent of ROS suppression. Our data show that the $O$. octandra extract functions as an antioxidant to diminish ROS generation in OSCC cells. Next, we observed that the treatment with O. octandra extract increased annexin V-positive cells and induced apoptosis via induction of caspase-3 in both types of OSCC cells. Consistent with these observations are data that suggest that high amounts of antioxidants can lead to cellular apoptosis via caspase cascade in OSCC cells $[19,20]$. Apoptosis of tumor cell is a complex process involving the regulation of numerous genes, including members of the Bcl-2 family, which are among the most important members as they are able to inhibit the apoptosis of cells [21]. The mitochondrial apoptosis pathway is mediated by anti-apoptotic and pro-apoptotic proteins, including the Bcl-2 family and Bax proteins [21, 22]. Thus, we observed the protein expression of $\mathrm{Bcl}-2$ family proteins, including $\mathrm{Bcl}-2, \mathrm{Bcl}-\mathrm{XL}$, and Bax. The protein levels of Anti-apoptotic Bcl-2 and $\mathrm{Bcl}-\mathrm{X}_{\mathrm{L}}$ were shown at an earlier $(6 \mathrm{~h})$ treatment time point after treatment with O. octandra extracts in both types of OSCC cells. Conversely, the protein expression of pro-apototic Bax was only shown increased levels at $12,24 \mathrm{~h}$ after treatment with $\mathrm{O}$. octandra extracts in HSC2 cells. There is no alteration of Bax protein in YD10B cells. However, the ratio of pro-apoptotic protein/anti-apoptotic protein could facilitate the cellular apoptosis [23, 24], thus $O$. octandra extract-induced cell death is involved in cellular apoptosis. We further investigated whether $O$. octandra extract-induced apoptosis is involved in extrinsic or intrinsic apoptosis pathway. Apoptosis can be initiated through activation of the extrinsic (receptor) pathway or intrinsic pathway [21]. In extrinsic pathway, activation of death receptors, such as tumor necrosis factor (TNF) $-\alpha$ and Fas with its ligand FasL, triggers the formation of a death-inducing signaling complex (DISC) involving the recruitment of the adaptor protein FADD. Following its recruitment, it activates caspase-8, in turn can cleave apoptotic substrates like caspase- 3 and bid $[25,26]$. Our findings provide that a weakly increased expression of Fas in HSC2 cells, whereas a decreased expression of Fas in YD10B cells, compare with control cells $(0 \mathrm{~h})$. Additionally, we cannot observe the tendency by $O$. octandra extract in protein expression of caspase- 8 and bid, meaning that $O$. octandra extract-induced apoptosis is not involved in extrinsic pathway. Furthermore, an increase of caspase- 9 protein was shown at $12 \mathrm{~h}$ in YD10B cells and at $24 \mathrm{~h}$ in HSC cells, respectively, but cleavage of caspase- 9 was not detected. Although caspase- 9 is an upstream effector of caspase-3 in intrinsic apoptosis pathway, the protein expression of cleaved caspase- 3 was increased at an earlier time point (from $6 \mathrm{~h}$ after treatment with $O$. octandra extract) than at time point when increased expression of caspase- 9 was shown. It is indicated that caspase- 3 can be activated by $O$. octandra extract-triggered several signals such as caspase-2/7, BNIP, Bcl-2 family protein, NF-kB and MAPK [21, 2729]. Taken together, O. octandra extract-induced apoptosis is not involved in death receptor mediated extrinsic pathway. However, it is involved in caspase-3 cascade and it might be regulated by internal stimuli such as DNA damage and by Fas/Caspase-8 independent pathway [27]. To clear the hypothesis, further studies are required for in-depth understanding of the signaling pathway of apoptosis induced by the O. octandra extract.

Collectively, $O$. octandra extract increased cellular apoptosis through $G_{1}$ cell cycle arrest and a caspase 3 cascade-dependent pathway in OSCC cells. However, our research has some study limitations. We only used one type of normal cells, and thus other types of normal cells should also be examined to unequivocally establish that $O$. octandra leaf extract is not toxic to normal cells. Furthermore, we did not identify what components from $O$. octandra extract can induce apoptosis. The leaf of $O$. octandra contains phenols, tannins, flavonoids, alkaloids and terpenoids [8]. Flavonoids function as antioxidants [30] and can induce $G_{0} / G_{1}$ arrest and apoptosis through p38/JNK MAPKinase in hepatocellular carcinoma cells [31]. Thus, MAPKinase might be involved in cellular apoptosis induced by the O. octandra extract in OSCC cells. Additionally, terpenoids can also induce cell cycle arrest and apoptosis, and increase the amount of ROS as well [32]. In addition, phenols, tannins and alkaloids have also been implicated in anticancer and antioxidant activity of phytochemicals [33-35]. However, the specific bioactive compounds of $O$. octandra that induce cell cycle arrest and apoptosis in OSCC cells are still unknown. Thus, further studies are required to identify the specific compounds that confer anticancer and antioxidant properties to the leaf extract of $O$. octandra. 


\section{Conclusion}

A leaf extract of $O$. octandra inhibited the proliferation of OSCC cells in vitro through cell cycle arrest in $G_{1}$ phase and interrupting DNA replication; the extract $(\leq 100 \mu \mathrm{g} /$ $\mathrm{ml}$ ) had little or no cytotoxicity in normal keratinocytes. The leaf extract of $O$. octandra could trigger the apoptotic response via caspase 3 activation in OSCC cells. These findings could lead to the development of novel herbal medicines from $O$. octandra, specifically targeting OSCC cells.

\section{Abbreviation}

OSCC: Oral squamous cell carcinoma.

\section{Supplementary Information}

The online version contains supplementary material available at https://doi. org/10.1186/s12906-022-03505-4.

\section{Additional file 1. \\ Additional file 2 . \\ Additional file 3. \\ Additional file 4. \\ Additional file 5. \\ Additional file 6. \\ Additional file 7.}

\section{Acknowledgements}

We thank Dr. Chamila Liyanaarachchie for assistance in the preparation of Osbeckia octandra leaf extract and Xianglan Zhang (Yanbian University Medical of College and Yonsei University College of Dentistry) who greatly encouraged us to continue this study.

\section{Authors' contributions}

All authors have read and approved the final manuscript and have made a sufficient contribution to the work. Conceptualization and resources, B.M.R.B. and W.M.T.; investigation, data analysis and validation, J.Y.K. and D.K.; writing - original draft preparation, J.Y.K, J.K. and D.K.; writing — review and editing, D.K., B.M.R.B. and W.M.T; funding acquisition, J.K. and D.K.; writhing - revised manuscript, J.Y.K. and D.K.

\section{Funding}

This research was supported by the S \& T Support Program for Developing Countries funded by the Ministry of Sciences, ICT, and Future plan (2013K1A3A9A01044071) and Basic Science Research Program through the National Research Foundation of Korea (NRF) funded by the Ministry of Education (2021R1I1A1A01045571).

\section{Availability of data and materials}

The datasets generated and analyzed during the current study are available from the corresponding author on reasonable request.

\section{Declarations}

\section{Ethics approval and consent to participate}

The YD OSCC cells and HSC2 OSCC cells used in our study were commercially available in the Cell Line Bank of Korea and Japan, respectively. Human normal epidermal keratinocytes (HEK) were previously obtained from healthy normal foreskin. This work has been carried out in accordance with the Declaration of Helsinki and involved in the informed consent from the patients. These procedures were approved by the Institutional Review Board (IRB) of the
Yonsei Dental Hospital, Seoul, Republic of Korea (IRB-2-2009-0002) as in our previous study [10].

\section{Consent for publication}

Not applicable.

\section{Competing interests}

The authors declare that they have no competing interests.

\section{Author details}

${ }^{1}$ Oral Cancer Research Institute, Department of Oral Pathology, Yonsei University College of Dentistry, Seoul 03722, Republic of Korea. ${ }^{2}$ Department of Obstetrics and Gynecology, Gangnam Severance Hospital, Yonsei University College of Medicine, Seoul 06230, Republic of Korea. ${ }^{3}$ Department of Chemistry, Faculty of Science, University of Peradeniya, Peradeniya 20400, Sri Lanka. ${ }^{4}$ Department of Oral Pathology, Faculty of Dental Sciences, Center for Research in Oral Cancer, University of Peradeniya, Peradeniya 20400, Sri Lanka. ${ }^{5}$ Department of Oral Maxillofacial Clinical Sciences, Faculty of Dentistry, University of Malaya, Kuala Lumpur 50603, Malaysia. ${ }^{6}$ Precision Medicine Research Center, Department of Biomedicine \& Health Sciences, College of Medicine, The Catholic University of Korea, Seoul 06591, Republic of Korea.

Received: 28 April 2021 Accepted: 22 December 2021

Published online: 25 January 2022

\section{References}

1. Yin SY, Wei WC, Jian FY, Yang NS. Therapeutic applications of herbal medicines for cancer patients. Evid Based Complement Alternat Med. 2013:2013:302426.

2. Jiao L, Bi L, Lu Y, Wang Q, Gong Y, Shi J, et al. Cancer chemoprevention and therapy using chinese herbal medicine. Biol Proced Online. 2018;20:1.

3. Li-Weber M. Targeting apoptosis pathways in cancer by Chinese medicine. Cancer Lett. 2013;332:304-12.

4. Kim A, Im M, Hwang YH, Yang HJ, Ma JY. Jaeumganghwa-tang induces apoptosis via the mitochondrial pathway and Lactobacillus fermentation enhances its anti-Cancer activity in HT1080 human Fibrosarcoma cells. PLoS One. 2015;10:e0127898.

5. Rahman A-u. Studies in natural products chemistry. Amsterdam; New York: Elsevier; 1988. p. v. <1-24, 6-9, 36-42, 7-50, 2-3>.

6. Thabrew MI, Hughes RD, Gove CD, Portmann B, Williams R, McFarlane IG. Protective effects of Osbeckia octandra against paracetamol-induced liver injury. Xenobiotica. 1995;25:1009-17.

7. Thabrew MI, Gove CD, Hughes RD, McFarlane IG, Williams R. Protective effects of Osbeckia octandra against galactosamine and tert-butyl hydroperoxide induced hepatocyte damage. J Ethnopharmacol. 1995;49:69-76.

8. Madhusha Prasadani SB, Illeperuma RP, Kodithuwakku SP. Leaf extract of Osbeckia octandra L. (Heen Bovitiya) suppresses human Oral squamous cell carcinoma cells migration and induces cellular DNA damage. J Oral Maxillofac Surg Med Pathol. 2021;33:6.

9. Eun Ju Lee JK, Lee SA, Kim E-J, Chun Y-C, Ryu MH, Yook J-I. Characterization of newly established oral cancer cell lines derived fromsix squamous cell carcinoma and two mucoepidermoid carcinoma cells. Exp Mol Med. 2005;37:12.

10. Illeperuma RP, Kim DK, Park YJ, Son HK, Kim JY, Kim J, et al. Areca nut exposure increases secretion of tumor-promoting cytokines in gingival fibroblasts that trigger DNA damage in oral keratinocytes. Int J Cancer. 2015;137:2545-57.

11. P.R.D Perera SE, K.K.D.S. Ranaweera. In vitro study on antiglycation activity,antioxidant activity and phenolic content of Osbeckia octandra L. leaf dec. J Pharmacognosy Phytochemistry. 2013;2:3.

12. Marsh D, Suchak K, Moutasim KA, Vallath S, Hopper C, Jerjes W, et al. Stromal features are predictive of disease mortality in oral cancer patients. J Pathol. 2011;223:470-81.

13. Buglione M, Cavagnini R, Di Rosario F, Sottocornola L, Maddalo M, Vassalli $L$, et al. Oral toxicity management in head and neck cancer patients treated with chemotherapy and radiation: dental pathologies and osteoradionecrosis (part 1) literature review and consensus statement. Crit Rev Oncol Hematol. 2016;97:131-42. 
14. Villa A, Akintoye SO. Dental Management of Patients who Have Undergone Oral Cancer Therapy. Dent Clin N Am. 2018;62:131-42.

15. Pietenpol JA, Stewart ZA. Cell cycle checkpoint signaling: cell cycle arrest versus apoptosis. Toxicology. 2002;181-182:475-81.

16. Masamha CP, Benbrook DM. Cyclin D1 degradation is sufficient to induce G1 cell cycle arrest despite constitutive expression of cyclin E2 in ovarian cancer cells. Cancer Res. 2009;69:6565-72.

17. Casimiro MC, Velasco-Velazquez M, Aguirre-Alvarado C, Pestell RG. Overview of cyclins D1 function in cancer and the CDK inhibitor landscape: past and present. Expert Opin Investig Drugs. 2014;23:295-304.

18. Chehab NH, Malikzay A, Appel M, Halazonetis TD. Chk2/hCds 1 functions as a DNA damage checkpoint in $\mathrm{G}(1)$ by stabilizing p53. Genes Dev. 2000;14:278-88.

19. Kwak HH, Kim IR, Kim HJ, Park BS, Yu SB. Alpha-Mangostin induces apoptosis and cell cycle arrest in Oral squamous cell carcinoma cell. Evid Based Complement Alternat Med. 2016;2016:5352412.

20. Chen SF, Nien S, Wu CH, Liu CL, Chang YC, Lin YS. Reappraisal of the anticancer efficacy of quercetin in oral cancer cells. J Chin Med Assoc. 2013;76:146-52.

21. Carneiro BA, El-Deiry WS. Targeting apoptosis in cancer therapy. Nat Rev Clin Oncol. 2020;17:395-417.

22. Nakano K, Vousden KH. PUMA, a novel proapoptotic gene, is induced by p53. Mol Cell. 2001;7:683-94.

23. Raisova M, Hossini AM, Eberle J, Riebeling C, Wieder T, Sturm I, et al. The $\mathrm{Bax} / \mathrm{BCl}-2$ ratio determines the susceptibility of human melanoma cells to CD95/Fas-mediated apoptosis. J Invest Dermatol. 2001;117:333-40.

24. Perlman H, Zhang X, Chen MW, Walsh K, Buttyan R. An elevated bax/bcl-2 ratio corresponds with the onset of prostate epithelial cell apoptosis. Cell Death Differ. 1999;6:48-54.

25. Nagata S. Apoptosis by death factor. Cell. 1997;88:355-65.

26. Kantari $\mathrm{C}$, Walczak H. Caspase-8 and bid: caught in the act between death receptors and mitochondria. Biochim Biophys Acta. 2011;1813:558-63.

27. Ochs K, Kaina B. Apoptosis induced by DNA damage O6-methylguanine is $\mathrm{BCl}-2$ and caspase- $9 / 3$ regulated and Fas/caspase- 8 independent. Cancer Res. 2000;60:5815-24.

28. Liu G, Zou H, Luo T, Long M, Bian J, Liu X, et al. Caspase-dependent and Caspase-independent pathways are involved in cadmium-induced apoptosis in primary rat proximal tubular cell culture. PLoS One. 2016;11:e0166823.

29. Kim CG, Castro-Aceituno V, Abbai R, Lee HA, Simu SY, Han Y, et al. Caspase-3/MAPK pathways as main regulators of the apoptotic effect of the phyto-mediated synthesized silver nanoparticle from dried stem of Eleutherococcus senticosus in human cancer cells. Biomed Pharmacother. 2018;99:128-33.

30. Panche AN, Diwan AD, Chandra SR. Flavonoids: an overview. J Nutr Sci. 2016:5:e47.

31. Wang $D$, Sun $Q$, Wu J, Wang W, Yao G, Li T, et al. A new Prenylated flavonoid induces G0/G1 arrest and apoptosis through p38/JNK MAPK pathways in human hepatocellular carcinoma cells. Sci Rep. 2017;7:5736.

32. Chen HL, Lin KW, Huang AM, Tu HY, Wei BL, Hour TC, et al. Terpenoids induce cell cycle arrest and apoptosis from the stems of Celastrus kusanoi associated with reactive oxygen species. J Agric Food Chem. 2010;58:3808-12.

33. Dai J, Mumper RJ. Plant phenolics: extraction, analysis and their antioxidant and anticancer properties. Molecules. 2010;15:7313-52.

34. Lu JJ, Bao JL, Chen XP, Huang M, Wang YT. Alkaloids isolated from natural herbs as the anticancer agents. Evid Based Complement Alternat Med. 2012;2012:485042.

35. Amrati FE, Bourhia M, Slighoua M, Ibnemoussa S, Bari A, Ullah R, et al. Phytochemical study on antioxidant and Antiproliferative activities of Moroccan Caralluma europaea extract and its bioactive compound classes. Evid Based Complement Alternat Med. 2020;2020:8409718.

\section{Publisher's Note}

Springer Nature remains neutral with regard to jurisdictional claims in published maps and institutional affiliations.

Ready to submit your research? Choose BMC and benefit from:

- fast, convenient online submission

- thorough peer review by experienced researchers in your field

- rapid publication on acceptance

- support for research data, including large and complex data types

- gold Open Access which fosters wider collaboration and increased citations

- maximum visibility for your research: over $100 \mathrm{M}$ website views per year

At BMC, research is always in progress.

Learn more biomedcentral.com/submissions 